\title{
Towards European Rules of Civil Procedure: Rethinking Procedural Obligations
}

\begin{abstract}
Alan Uzelac*
Abstract. From Transnational Principles to European Rules of Civil Procedure is a joint project of the European Law Institute (ELI) and the International Institute for the Unification of Private Law (UNIDROIT). This paper gives a systematic presentation of the progress by one of the project's working groups tasked with the elaboration of rules on the obligations of parties, lawyers and judges using as a starting point Principle 11 of the Transnational Principles of Civil Procedure produced by the American Law Institute (ALI) and UNIDROIT. Since November 2014, progress by the Working Group has advanced, resulting in a number of draft rules dealing with procedural obligations (and sanctions for their breach) related to case management, pleading of facts, evidence and law and the efforts to achieve autonomous settlement of civil disputes. The paper describes the major achievements of this work, emphasising several important changes in comparison to the conventional approach to procedural obligations.
\end{abstract}

Keywords: obligations of parties, obligations of lawyers, obligations of judges, civil procedure, transnational rules of civil procedure

\section{INTRODUCTION}

European integration processes may not currently be on the rise, but the process of approximation of national judicial procedures in Europe, which has been considered since the 1980 s, is still on the agenda. ${ }^{1}$ Judicial procedures have long remained a purely national regulatory object but several developments in the past decades have given impetus to a movement towards 'Europeanisation' of procedural law on multiple levels. ${ }^{2}$ One development arising out of the crisis in many national civil justice systems, is the universal need for well-planned procedural reforms that will address the serious problems of excessive caseloads, costs and delays in civil litigation. ${ }^{3}$ There is also pressure from the national economies of the EU countries, which requires that the proclaimed mutual trust in national judiciaries be converted into judicial practices that factually support the free movement of goods and services in the European Area of Justice. Though EU competence in the field of civil procedure is limited, the emerging body of EU legislation, despite its

* M.A., LL.D., Professor and Head of Department for Civil Procedure at Faculty of Law, Zagreb University, European Law Institute, Trg m. Tita 14, HR-10000 ZAGREB auzelac@pravo.hr. This paper is inspired by teamwork and the intense exchange of ideas within the ELI-UNIDROIT Working Group on Obligations of Parties, Lawyers and Judges. I am grateful for the constructive input provided by all of the group members. Special thanks go to my co-reporter, Professor C.H. van Rhee, who gave the decisive initial impetus and contributed greatly to the methodology of our work. I am also indebted to Mr. Randolph Davidson, who improved the language of this paper and to Ms. Ala Šabanović, who kindly assisted me in the transformation and upgrade of my keynote speech delivered at the European Law Institute's Ferrara annual conference in September 2016. The research for this paper was supported by a grant from the scientific project NHPS of the University of Zagreb Faculty of Law

${ }^{1}$ For initial attempts at approximation, see Storme (1994).

2 On 'Europeanisation' of procedural law, see Ervo et al. (2009), Manko (2015).

3 See Zuckerman (2000), also for global developments. 
fragmentary nature, has sparked discussions about the development of common minimum standards of a more general nature. ${ }^{4}$ Rather than a piecemeal approach, common minimum standards are best achieved if they are rooted in a coherent and comprehensive set of principles and rules that are a product of broad expert study of best practices and common trends in national and international civil procedures.

Against this backdrop, the echo of the Transnational Principles of Civil Procedure 5 around the world have encouraged further projects aimed at the production of more comprehensive and detailed regional rules. In this paper, a part of one of the most ambitious and promising projects, the project of drafting European Rules of Civil Procedure, is presented. Though this project is still a work-in-progress, in some areas significant progress has already been achieved. The focus here is on the topic of procedural obligations, i.e. on the provisional results obtained by the team of experts entrusted to produce a European set of rules on the obligations of parties, lawyers and judges.

\section{GENERAL OVERVIEW AND THE MANDATE OF THE ELI-UNIDROIT WORKING GROUP ON OBLIGATIONS OF PARTIES, LAWYERS AND JUDGES}

The Working Group on Obligations of Parties, Lawyers and Judges was established within the joint project From Transnational Principles to European Rules of Civil Procedure undertaken by the European Law Institute (ELI) and the International Institute for the Unification of Private Law (UNIDROIT) beginning in November 2014. ${ }^{6}$ The aim of the Working Group is to elaborate European rules of civil procedure following in particular the approach of the American Law Institute (ALI) and UNIDROIT Transnational Principles - Principle 11 (Obligations of Parties and Lawyers). ${ }^{7}$ Based on extensive discussions and preparatory materials, the Working Group concluded that a balanced presentation of procedural obligations could not be achieved without equal consideration given to the obligations of judges and consequently, it added this element to its name.

\section{THE APPROACH AND GENERAL STRUCTURE OF THE PROPOSED RULES}

As a starting point, the Working Group found that Principle $11^{8}$ of the ALI/UNIDROIT transnational rules could serve as a basis for the elaboration of European rules on obligations. Principle 11 not only contains acceptable provisions, but also corresponds to the modern trends in the reform of civil procedure. While maintaining the essence of the ALI/UNIDROIT Principles, which deal with relevant aspects of the obligations of parties,

${ }^{4}$ On the notion of procedural standards and recent study of the situation in Europe, see a very comprehensive recent review produced for the European Parliament by Tulibacka et al. (2016) 5-6.

5 ALI/UNIDROIT Transnational Principles of Civil Procedure (2005).

${ }^{6}$ On this project, see more on the web pages of respective organisations: <http://www. europeanlawinstitute.eu/projects/current-projects> accessed 6 June 2017 and $<$ http://www.unidroit. org/work-in-progress-studies/current-studies/transnational-civil-procedure > accessed 6 June 2017. The members of the Working Group are Jeuland, (Paris), Karolczyk (Warsaw), Rechberger (Vienna), Silvestri (Pavia), Sorabji (London), Strandberg (Bergen). The appointed co-reporters are Rhee (Maastricht) and Uzelac (Zagreb).

7 ALI/UNIDROIT Transnational Principles (2005) 20-21.

8 ALI/UNIDROIT Transnational Principles (2005) 20-21. 
their lawyers and judges, the rules elaborated by the Working Group also consulted various other sources. It is important to note that many other ALI/UNIDROIT Principles were taken into account and not only Principle 11, which focuses on the obligations of parties and lawyers.

Among other sources, the Working Group considered relevant recommendations of the Council of Europe (in particular, the 1984 Recommendation on civil procedure ${ }^{9}$ ), the case law of the highest European tribunals (the Court of Justice of the European Union and the European Court of Human Rights), various attempts to harmonise European civil procedure (starting with the 'Storme Project' ${ }^{10}$ ), diverse materials on comparative civil procedure (model codes such as Codigo modelo Ibero-americano ${ }^{11}$ and national law of various European states) and professional codes of conduct, in particular the Code of Conduct of European Lawyers of the Council of Bars and Law Societies of Europe (CCBE). ${ }^{12}$ A stocktaking exercise enabled the Working Group to combine various components into a coherent whole with a significant capacity for harmonisation owing to its content, which is at least partly familiar and common.

The main idea that permeates all of the proposed rules, using the language of Principle 11 , is the idea of shared responsibility of both the parties (and lawyers) and the court for a fair, efficient and speedy resolution of the civil proceedings. This idea, in the view of the Working Group, transcends the customary opposition between adversarial proceedings in which parties, as the dominant source of procedural actions, self-manage the proceedings and inquisitorial proceedings, dominated by the main responsibility of the court for the conduct, organisation and outcome of the proceedings, with little or no responsibility on the side of the parties. ${ }^{13}$

When consulting the history of reforms of civil procedure, a similar basic approach may be found in some of the most influential and successful national reform projects, from the prominent reform of the Austrian ZPO (Zivilprozessordnung) designed by Franz Klein in $1895^{14}$ to the reform of the English CPR (the Civil Procedure Rules) in 1999, led and coordinated by Lord Woolf. ${ }^{15}$ The same leading idea in those projects of the shared obligation of loyal cooperation, which is common to the court, the parties and the other professional actors in the proceedings (lawyers, etc.), underpins practically all of the rules compiled by the Working Group, because it considers overcoming the adversarialinquisitorial divide and the replacement of the dichotomy by a single, loyal cooperation principle (or, in the words of Franz Klein, 'loyal collaboration') as one of its most important tasks and at the same time achievements. The recognition of an overarching principle is also one of the main tools for the establishment of the general goal of civil procedure - fair, efficient, speedy and proportionate resolution of civil disputes.

9 Council of Europe Recommendation No. R (84) 5.

10 The Storme Commission was an unofficial body of academic experts from (at the time) every Member State which, with the financial support of the European Commission, investigated the possibilities of drafting a 'European Judicial Code of Civil Procedure'. See Storme (1994).

11 Código Iberoamericano de Ética Judicial (2006).

12 CCBE Charter of Core Principles (2013).

13 See van Rhee (2014) 689.

14 Dr. Franz Klein (1854-1926) was the 'father' of the Austrian Zivilprozessordnung. For his main ideas, see Klein (1891).

15 Lord Harry Kenneth Woolf (1933) was the 'father' of the English Civil Procedure Rules. See his reports: Access to Justice, Interim Report, (1995); Access to Justice, Final Report, (1996). 
In particular, it should be emphasised that, in contrast to some historical concepts that have seen 'collaboration' as a mutually exclusive division of labour, the proposed rules seek to extend the concept of shared obligations to all aspects of civil actions.

Previously, the customary understanding of the 'obligations' (also sometimes presented as cooperation between the parties and the court) presumed that the parties have the exclusive obligation to define some elements of the action, while the court defines the others. This understanding, typically used to explain the procedural dynamics regarding finding of facts and law, was epitomised in the Latin proverb da mihi factum, dabo tibi jus (Give me the facts, I will give you the law). Its meaning inter alia provided that the court has no obligations regarding facts and evidence and that the parties are free from any duties in the assessment of the legal issues, which are the exclusive domain of the court.

Following modern trends in civil procedure and the concept of the ALI/UNIDROIT Principles, the text of the proposed European rules recognises that the court and the parties (and all the other participants in civil proceedings) have certain obligations in respect of all the elements of litigation and thereby genuinely share responsibility for the course and outcome of the civil action in all of its aspects. ${ }^{16}$

These starting premises and the ensuing obligation of loyal cooperation were further elaborated in the rules, which are grouped into four sections, according to the object of the obligation.

The four sections that appear after the general part of the rules deal with:

- Case management and planning of the proceedings

- Determination of facts and evidence

- Determination of issues of law

- Attempts to reach settlement and use of ADR.

All four sections have a similar structure and contain separate rules on the obligations of the court, the parties and their lawyers and the sanctions for the breach of procedural obligations. They are, however, more specific and detailed in comparison to the general overview of obligations and sanctions contained in the general part. They regulate, for example, a number of particular issues, such as case management conferences and the use of alternative dispute resolution (ADR) techniques.

The main procedural obligation of the emerging rules (or, paraphrasing some codifications: an 'overarching obligation') is the obligation to act in a way that takes into account both the private interests of the litigants and the interests of the opponents, as well as the social desire to end disputes fairly, swiftly and at an appropriate cost. This obligation may be seen both as a positive and as a negative obligation. ${ }^{17}$ While its positive dimensions require the parties to conduct their actions in good faith and undertake steps instrumental to reaching the set goal, in its negative dimension this obligation requires that the parties refrain from all forms of abuse of the process.

In any case, for the obligations to be operative, concrete and effective sanctions are needed. The Working Group considered sanctions both within the general part and within the four individual sections (in the 'special part'). It was found that, aside from some

16 The questionnaires exchanged between the members of the Working Group revealed that taking of evidence can increasingly be ordered ex officio, at least in some cases, and that legal arguments are often required from the parties. As for England, John Sorabji even stated that under present case law 'judges cannot go beyond the legal issues as disclosed by the pleadings and put into issue by the parties' (but have a right to suggest to the parties that they amend their legal positions).

17 See van Rhee (2014) 693-94 (analysing Principle 11). 
common matters, no single and uniform rules on sanctions are appropriate, as various actors and elements of the procedural obligations require various types and forms of sanctions. Therefore, each section contains, in addition to the summary rules provided in the general part, elaborate provisions on the consequences that are envisaged for specific violations of procedural obligations.

The actors (or subjects) in respect of the procedural obligations include in the first place the parties to the dispute and a judge or a panel of judges entrusted with their case. For performing certain obligations, especially where case management is concerned, the judges need to be assisted by broader organisational structures within the court, this includes their clerks and reporters and general bodies entrusted with judicial administration (presidents of the court, court managers, IT personnel, etc.). To that extent, the rules mentioning 'court' or 'judges' include the powers and responsibilities of all existing structures that ensure good administration of justice in the concrete case.

Procedural obligations concern all professionals who are instrumental in performing the functions either of the court or of the parties. On the side of the court, judges (both professional and non-professionals, including jurors and assessors where they exist) may be assisted not only by employees of the court, but also by experts engaged by them, private bailiffs and others. When such persons act in concrete civil litigation performing various activities on behalf of the court, the obligations of the judges accordingly apply to them. On the side of the parties, lawyers are the most important actors in the proceedings and therefore their obligations are specifically targeted. However, if other professionals such as party-appointed experts and advisors appear on behalf of the parties, engaged by them to cover specific issues, procedural obligations of the parties and their lawyers also relate to them. Indeed, all such actors may also be subject to sanctions if they fail to perform their respective obligations.

\section{PARTICULAR SECTIONS OF THE DRAFT RULES}

\section{A. Case management and planning of the proceedings}

To achieve the common goal of a fair, efficient, speedy and proportionate resolution of civil disputes, adequate planning and organisation of the proceedings are of the utmost importance. Therefore, the first special section of the proposed rules deals with obligations of the court and the parties in regard to case management. Case management has been recognised as essential to securing the right to a trial within a reasonable time in a number of European jurisdictions, as well as in other jurisdictions around the world. ${ }^{18}$ In this sense, the proposed rules follow this trend, starting with the obligations related to case management and planning of the proceedings.

In line with modern trends, the rules emphasise the responsibility of the court for active and effective case management. This obligation is discharged by various case management orders and activities and by continual monitoring of whether the obligations of the parties, lawyers and other participants in the proceedings are observed. Moreover, the active management of proceedings under the court's direction also assumes the duty to consult the parties and, wherever possible, secure agreement on the form, content and timing of particular steps in the proceedings.

18 On recent trends in a number of countries, see e.g. van Rhee \& Fu (2014). See also Uzelac (2014) 15-20. 
While managing proceedings, the court should also take account of the nature, value and complexity of the particular proceedings, ensuring that procedures (the number of procedural steps like hearings or submissions; procedural means, in particular the use of expert witnesses, documents and witnesses; duration of the proceedings and their expense) are proportionate to the value and importance of the case.

The parties and all other participants have a duty to cooperate with each other and the court in planning procedural steps and their timetable. This duty is both negative and positive. The parties should refrain from delaying tactics and other forms of procedural abuse. They should also actively contribute to the proper planning and management of the procedure, presenting their positions and arguments regarding proposals by the court and the other party at the earliest opportunity.

An important tool for exercising the parties' right and obligation to contribute to case management was provided in the draft Rules under the 'Case Management Conference' section. The Case Management Conference is a preliminary hearing, which in principle should be held early in the litigation process, also if possible using means of communication such as tele- or video-conferencing. Following the best practices of European national jurisdictions, the Case Management Conference may, if the case is sufficiently clear, also lead to a decision on the merits (e.g. a summary judgment). ${ }^{19}$

In case management decisions, however, the proposed rules give the leading role to the court, which can issue orders on case management matters also on its own initiative and, if necessary, on an ex parte basis e.g. in cases of emergency. All the same, also in such cases party cooperation should be secured, allowing the parties to react within the shortest time possible. The powers of the court to issue ex parte orders, based on the consideration of fairness and in the form that is proportionate to the protected interests, follow the approach of ALI/UNIDROIT. ${ }^{20}$

The proposed rules also contain an extensive, but non-exhaustive, list of means of planning and case management, giving the court various options for an economical and fair organisation of the proceedings, allowing early identification and decision of all relevant issues in a complete and appropriate manner. ${ }^{21}$ The court's duty of active case management also authorises judges to encourage the parties to identify the real issues in dispute and to openly discuss with the parties the appropriate steps and methods for dealing with these issues.

Sanctions imposed on parties for the lack of cooperation regarding case management may take the form of procedural preclusions e.g., banning a party from taking particular procedural steps or relying on a particular fact or evidence after a certain period. Eventually, cost orders and fines can also serve for this purpose. Sanctions can also be imposed on lawyers and other party representatives if they fail to discharge their obligations. If judges fail to carry out their case management duties, parties may request the transfer of the case to another judge and complain to bodies competent for judicial conduct and discipline.

19 Case management conferences were an important element of English procedural reforms, see Woolf (1996). They have gradually spread to the European continent. On recent developments regarding preparatory stages of civil proceedings in the European North and East, see Ervo \& Nylund (2016).

20 See ALI/UNIDROIT Principles, at 5.8.

${ }^{21}$ Such exemplary listing is contained in several European procedural codes. For example, see Norwegian Dispute Act, section 9-4, second subsection. 


\section{B. Determination of facts and evidence}

With respect to the presentation of facts and evidence necessary for deciding on the merits of the case, the proposed draft Rules start with a provision commonly accepted in European jurisdictions to entrust the obligation for the identification of the matter in dispute to the parties and their lawyers. ${ }^{22}$ It is, however, also provided that such presentation should be made as early as possible, in a diligent, complete and timely fashion. Following the principle of concentration, which is another feature of modern procedural reforms, the presentation of facts and evidence at a later stage is allowed only for justified reasons. This approach (the 'cards on the table' approach ${ }^{23}$ ) considers the presentation of facts both as a right and as an obligation, in particular regarding the duty to act in a way that does not obstruct or delay the proceedings by introduction of late or obviously irrelevant factual allegations and evidence. In principle, the facts and evidence submitted after the expiration of relevant time limits or procedural stages should be disregarded by the court, such consequence being both incentive for full and speedy presentation of one's case and 'sanction' for attempts to abuse the proceedings.

Though the parties have the leading role in the introduction of facts and evidence, the proposed rules provide that the court may also consider the facts that appear in the case file or take evidence on its own motion if it is necessary, in the court's opinion, for the proper adjudication of the case. Indeed, the court should inform the parties about such ex officio steps and allow them to comment and react. This position taken in the proposed rules follows the tradition, common to many European countries, of allowing the court the discretion to actively intervene in factual and evidential issues in order to eliminate judicial injustice or abuse of judicial proceedings. ${ }^{24}$ In a well-organised litigation process, it is to be expected that the court would use this right rarely, only in exceptional circumstances.

Within its general case management duty, the court also has the right and the duty to sanction the inactivity of the parties, i.e. their failure to timely introduce necessary facts and evidence. The first rule provides that, if a party fails to substantiate its claim on time, the court may consider the claim withdrawn. Furthermore, considering that the current European systems have different attitudes towards the means available for the sanctioning of the parties' passive behaviour (which also may depend on the nature and type of case), the proposed draft Rules list a number of possible actions, which, in accordance with the applicable procedural rules, may be at the court's disposal in the event a party fails to respond to the factual allegations or evidence of the opposing party on time. These include issuing a default judgment, considering the facts to have been admitted entirely or partially and continuing the proceedings and deciding on the merits based on the available facts and evidence. If late presentation of evidence caused extra costs, they should be borne by the party that presented the late evidence regardless of the outcome of the case.

22 All members of the Working Group confirmed this submission for their own jurisdictions.

23 This expression is to be found in the Woolf reports. See also van Rhee (2014) 692.

${ }^{24}$ See for instance $\S 183$ of the Austrian Code of Civil Procedure (ZPO), allowing judges to order the parties to submit certain evidence if it is considered necessary for the establishment of disputed facts. Some procedural reforms in the transition countries have reduced the ability of judges to take evidence on their own initiative, but such interventions - aimed at reversal of paternalistic trends from the socialist past - generally have not achieved the desired effects. See more in Uzelac (2014a). 
Another means for the concentration of proceedings and proper planning of the action provided in the proposed rules is the court's order to close the proceedings once it is satisfied that both parties have had a reasonable opportunity to present their case. The date of closing the proceedings will be fixed as early as possible. The order has to clearly delineate a procedural phase, in which parties through their submissions, factual arguments and presentation of evidence develop their case and defences to their opponent's arguments, from the procedural phase, in which a decision on the merits is prepared through legal arguments and the court's deliberations. After the closure of the proceedings, in principle, no further submissions, arguments or evidence is allowed, though the court can exceptionally request or permit additional facts and evidence necessary to clarify the respective positions of the parties.

\section{Determination of issues of law}

A balanced relationship between the obligations of the court and the obligations of the parties also exists in the rules regarding the determination of issues of law. Both the court and the parties should contribute to the determination of the correct legal basis for the decisionmaking. Indeed, the court plays a directive role in this situation. As is the case in most European systems of civil procedure, the parties have a right and obligation to present their legal arguments. The main responsibility for the proper determination of legal issues, however, belongs to the court, which is the ultimate evaluator of all legal contentions in the case.

The specific rules proposed in this section that address some issues on which national jurisdictions have differing views deal with the level and extent of the obligations of particular procedural actors. In the first place (again, differently from the traditional da mihi factum, dabo tibi jus approach), the rules provide that the parties have the obligation to present their contentions of law in reasonable detail. In principle, they will present their legal arguments already at the initial stage of the proceedings. This rule is substantially identical to the approach of the ALI/UNIDROIT Principles. ${ }^{25}$

The second point, in which the proposed rules are also consistent with the ALI/ UNIDROIT Principles, deals with the right of the court to consider points of law on its own initiative if this is necessary for correct decision-making. The right of the court to rely on a legal theory that has not been advanced by the parties is contained in Principle 22.2.3. It is also the core of the universally accepted iura novit curia principle.

The right of the court to consider points of law ex officio should not render ineffective the obligation of the parties to present their legal arguments and react to the legal arguments introduced by the other party or the court. The consequences of the breach of this obligation, however, are differentiated. The sanctions are stricter if a party is legally represented, since it is assumed that lawyers are capable of pleading a case professionally. Thus, they are also obliged to present the legal contentions of represented parties at an appropriate procedural stage. To that extent, the Working Group considered it is legitimate that in case of a breach of this obligation, the ultimate sanction could include rejection of a statement of claim or another submission that does not contain sufficiently detailed contentions of law. ${ }^{26}$ Indeed, in socially sensitive cases the court will regularly refrain from using such an authority to summarily dismiss the case. This measure should be the ultimate means that depends on the court's discretion and assessment of the concrete circumstances of the case.

25 See ALI/UNIDROIT Principles, at 11.3 and 19.1.

26 See mutatis mutandis Principle 17.3 of the ALI/UNIDROIT Principles. 


\section{Attempts to reach settlement and use of ADR}

The last section of the proposed rules on obligations of the parties, lawyers and judges addresses an important topic that has been high on the agenda of the procedural reforms of almost all European jurisdictions since the 2000s. This topic consists of an obligation to cooperate in dispute resolution attempts, which could lead to voluntary and out-of-court settlement of the case. The main (but not the only) way which may lead to the agreed mandatory solutions without the need to issue a judicial judgment is direct or assisted negotiations and mediation.

Faced with scarce resources and the long duration of judicial proceedings, European jurisdictions increasingly embrace the approach according to which the parties should not engage in the machinery of civil justice unless they have a real need for judicial protection because they cannot obtain the same result elsewhere in a simpler and cheaper way. In regular civil cases, resorting to the courts should, in principle, be a measure of last resort - the ultimum remedium. In particular, judicial proceedings should not be used as a replacement for the poor communication of the parties in dispute and their inability to present and define their claims and views to the other side. Hence, the main rule should provide that the parties must cooperate actively in seeking to resolve their dispute consensually, both before and after the proceedings are begun.

For this purpose, the proposed draft Rules provide a list of mandatory and optional steps to be undertaken in the pre-action and action phases of the proceedings. Before the initiation of the judicial proceedings, the parties should identify their claims and defence and exchange sufficient details, in particular the evidence on which such claims and defence are based. They should also clarify and, wherever possible, narrow down the legal and factual issues in dispute. Further recommended steps in the pre-action phase include the exchange of the settlement proposals or proposals for the use of appropriate resolution methods, among others e.g., concluding an agreement on arbitration, or engagement in a mediation of the dispute.

Lawyers have a particular place in the promotion of out-of-court settlements. Their role is not just to formulate the claims of the parties and present them to the court. Before a court action is considered, the lawyers should inform the parties about other available alternatives. They should encourage the parties to negotiate, help them in settlement negotiations and inform them about the availability of alternative dispute resolution methods. A legal and professional duty of lawyers is also to use the ADR proceedings conscientiously and in good faith, avoiding any abuse, delaying tactics and obstruction of the proceedings.

Judicial obligations to facilitate settlement attempts and promote the effective use of ADR are equally important. Judges should encourage consensual dispute resolution at any stage of the proceedings, in particular, at the preparatory stage of the proceedings and at Case Management Conferences. If the court-annexed mediation or appropriate out-ofcourt ADR schemes are available, the court has a duty to inform the parties about them. In appropriate cases, judges are authorised to assist the parties in reaching a consensual solution of the dispute, while respecting their obligation to be and remain independent and impartial. It is also appropriate for a judge to contribute to the actual drafting and homologation of the settlement agreements reached during or before the court proceedings.

The proposed draft Rules define the compulsory means that the court may use to enforce the parties' obligation to attempt to resolve the dispute autonomously. These means are only indicative and should depend, in the view of the Working Group, on the provisions of special legislation adapted to the peculiarities of particular types of cases. If such a basis 
exists, the court will, in appropriate cases, issue an order by which the parties are obliged to undertake specific steps e.g. exchange evidence or settlement proposals, attend one or more information sessions on the use of ADR, or participate in one or more ADR schemes alone or assisted by their lawyers. The court may stay the proceedings or reject the parties' submissions until the order to take the necessary steps is complied with.

While respecting the parties' right to access to the court but also the need to secure effective compliance with their obligation to attempt other available means before resorting to the court, the proposed draft Rules provide that if the law lays down a set of mandatory steps aimed at consensual dispute resolution that have to be exhausted prior to the court proceedings, the court will require the parties to undertake such steps and stay or discontinue the proceedings, which can be resumed or reinitiated after the required steps have been taken. This provision is in line with the approach of the EU Mediation Directive, ${ }^{27}$ which recognises the right of European Union Member States to make mediation compulsory or subject to incentives or sanctions, provided that the obligations and limitations of such mandatory process do not prevent the parties from exercising their right to access the judicial system. ${ }^{28}$ Indeed, the appropriate balance between the effective enforcement of the right to access the court and the obligation to exhaust other means before requesting judicial protection should be guaranteed by other special provisions in the national legislation.

The effective enforcement of the obligations of the parties or their lawyers to cooperate in consensual dispute resolution attempts requires an effective sanctions system. In addition to the preceding options (right of the court to stay or discontinue the proceedings or reject parties' submissions), the draft Rules provide that other available means to ensure the effective compliance with procedural obligations should be made available to the court and used at its discretion. Such means and sanctions, to be used in relevant cases (and, for some forms, subject to further regulation and bylaws), include cost sanctions, awarding of damages caused by the delay and procedural abuse, raising court fees, payment of fines and reporting to the respective professional organisation e.g., a bar association, for the imposition of professional sanctions. Although extensive, this catalogue of sanctions is not expected to be applied often - it only reinforces the authority of the court and increases the probability that procedural obligations of other participants in the proceedings will be observed. This includes the obligation to voluntarily enforce a concluded settlement agreement, which also belongs to one of the obligations of the parties.

\section{MOST IMPORTANT ISSUES TO BE DISCUSSED}

\section{E. Concept of procedural obligations and sanctions for their violation}

The traditional European civil procedure approach emphasises the distinction between 'procedural obligations' (Pflichten) and 'procedural burdens' (Lasten or 'mere obligations'). The older writings go so far as to argue that procedural obligations (duties that can be sanctioned by the court) do not exist. They argue that the parties in civil procedure (or their lawyers) are domini litis and therefore everything they undertake is a display of their will, not of any obligation they have. Consequently, failure to undertake specific steps may only

27 EU Directive 2008/52/EC on Certain Aspects of Mediation in Civil and Commercial Matters (2008).

28 EU Mediation Directive (2008) 136/4 at (14). 
be 'sanctioned' by the indirect sanction (or consequence) of losing their case. In a modern twist, the proposed draft Rules identify a number of strict procedural obligations which, if violated, can (also) lead to proper judicial sanctions. As the effective enforcement of basic procedural obligations was seen as the most important and overarching obligation, the draft Rules have not drawn a sharp distinction between Pflichten and Lasten. Both are covered by the same expression 'procedural obligations' or by simply pointing out what parties or lawyers should or should not do. ${ }^{29}$ Similarly, the draft Rules do not draw a clear line between 'sanctions' in the strict sense and the 'consequences' or 'implications' for the parties' (in)activity. It is debatable as to whether this should be considered a lack of clarity and precision or a pragmatically justified choice aimed at avoiding unnecessary conceptual disputes. It should, however, also be pointed out that the same 'imprecise' approach which treats Pflichten and Lasten under the same expression is shared by the ALI/UNIDROIT Principles.

\section{F. Legal obligations and professional obligations - rules of professional ethics in the context of rules of civil procedure}

A point upon which the proposed draft Rules differ from the approach taken by many contemporary European procedural codes (a strict separation of the rules of civil procedure and the rules of professional ethics) is the introduction of a stronger reference to separate and independent procedural obligations of legal professionals (in particular, lawyers). In the draft Rules, it is also indicated that not only procedural but also professional sanctions may (and should) be available in case of abuse of procedure. This is different from many procedural codes that generally cover only the obligations of the parties, treating lawyers as their 'alter egos' and referring to their obligations, if at all, only within the self-regulation of the legal profession.

The choice to include rules and provisions on lawyers and their professional obligations in the proposed draft Rules substantially follows the guidance of the ALI/UNIDROIT Principles. ${ }^{30}$ It was also decided that, while jurisdictions that wish to implement the ELI/ UNIDROIT Rules may choose to enact some of them in other acts or leave them to rules of professional ethics, this proposal, for the sake of completeness, should nevertheless give guidance as to the content of particular obligations and the sanctions for their nonobservance, no matter whether it would fit better in another act, statute or set of rules. Another reason behind such an approach was that, in practical terms, the role of lawyers is of ultimate importance for the fulfilment of the parties' obligations and that good administration of justice (or, on the other side, procedural delays and abuse of procedure) largely depends on their actions. To that extent, some rules, which can be found in certain ethical codes e.g., Code of Conduct for European Lawyers issued by $\mathrm{CCBE}^{31}$, may and should also be conceived as strict legal obligations. ${ }^{32}$ However, this is another point that may be revisited in discussions in more detail and the same is true for the relationship and interplay of the rules of civil procedure and the legal and ethical obligations of legal professionals.

29 cf. van Rhee (2014) 693.

30 The title of Principle 11 is clear: 'Obligations of the Parties and Lawyers'. Principle 11.5 also clearly refers to the professional obligation of lawyers. ALI/UNIDROIT Principles (2005) 20.

31 CCBE Code of Conduct (2013).

32 CCBE Code of Conduct (2013). see for instance rule 4.2. (duty of fairness) or rule 4.4. (prohibition of giving false or misleading information to the court). 


\section{G. Too many broad statements of 'principles', not enough 'rules'?}

The rules contained in the proposal are all drafted in a way that guarantees flexibility and a certain degree of generalisation. They also derive from one main idea or principle of the duty of all the civil procedure participants to cooperate in good faith for the purpose of a fair, economical and reasonably speedy process, thereby sharing responsibility for good administration of justice. The draft Rules do not attempt to define precise time limits for discharging the particular obligations or spell out exact sums in the event of fines or damages. Some civil procedural traditions in Europe may not be familiar with such an approach as they are more technical, which may leave them with the impression that the proposed rules contain more 'principles' than 'rules'.

The position of the experts working on the development of the ELI/UNIDROIT draft Rules was to avoid the formulation of very precise rules, as they would hardly be acceptable to everyone, particularly in light of the considerable differences in the structure and approaches of national jurisdictions in Europe. Moreover and more importantly, it was deemed that clear, general ideas contributed more to the success of most successful reforms of civil procedure in Europe than very detailed and formalised rules, which can distract from the main intentions and aims of the procedural regulation. However, it may be worth discussing whether the proposed draft Rules achieved the right balance between general rules and open standards, on the one hand and formal and precise technical provisions, on the other.

\section{H. Judicial discretion or strict rules?}

Further to the previous point, another issue dealing with the level of discretion of the court to implement the proposed rules and policies should be raised here. As mentioned before, in many cases, it seemed almost impossible to find universally applicable provisions which would automatically and without exception lead to correct results in all cases. Therefore, particularly where the case management decisions and sanctions for violations of procedural obligations are concerned, the rules leave a certain level of discretion to the court to make a prudent choice and form its decision based on the assessment of all the circumstances of the case. Some European civil jurisdictions, particular in the South and in the East of the continent, might not be very familiar with this approach, as they are hostile towards giving judges much (if any) discretion in their decision-making. A topic for discussion could be whether this tradition has been gradually changing in the light of modern reform trends and whether the existent judicial structures in Europe are ready and sufficiently capable of embracing a certain amount of prudent and reasoned discretion.

\section{Abandoning the da mihi factum, dabo tibi jus approach}

As outlined above, the proposed draft Rules incorporate another fundamental idea concerning the duty of loyal procedural cooperation and the principle of shared responsibility for fair, swift and effective proceedings, which require the active contribution of all the main participants in the process (parties, lawyers and judges), both at the organisation stage of the process and when elements essential to identify the disputed issues are being defined. Although the balance between the activism required from each side to the dispute might shift in such a way that in some aspects the parties have a more and the court a less, important role (and vice versa), there are no essential procedural spheres in which one side (parties and their lawyers) or the other (the court) would be exclusively responsible and the 
other side is discharged of any obligations. To that extent, the somewhat simplified but still largely influential formulas on one-sided responsibility such as da mihi factum, dabo tibi jus would not be accurate any longer. This also may be a topic for discussion.

\section{J. Limits and scope of obligation to attempt settlement and use the available ADR methods}

Approaches in Europe differ as to the issue of the encouragement of the parties to reach a mutually agreeable solution. While some national jurisdictions still think that any communication aimed at resolving the conflict should be merely voluntary and optional, others advocate for the use of broad mandatory schemes of pre-trial and ADR procedures before continuing to litigation. The proposed draft Rules attempt to strike a balance between these two poles and this may constitute another point for debate as to whether the chosen tactic is the right one.

The scope of ADR techniques and methods that parties would be required to exhaust may also be open to discussion. One point here relates to the scope of pre-action obligations, in particular with regard to the duty of mutual disclosure of claims and the related factual allegations with evidence supporting them.

Another point relates to the obligation to consider arbitration as an alternative to court proceedings. In this respect, although arbitration is certainly desirable in some kinds of cases and, in a broader sense, may be a part of the obligation to exhaust all appropriate means prior to court proceedings, it is not consensual in its outcome and may hardly become mandatory on a broader scale. Therefore, the Working Group decided to avoid specific references to arbitration and maintained the expression that addresses 'consensual dispute resolution', which may be another topic for discussion.

\section{K. Can language and terminology of procedural rules be harmonised across Europe?}

The work on the ELI/UNIDROIT Rules of civil procedure revealed a number of linguistic and terminological issues pertaining to the formulation of the provisions aimed to be accepted across Europe. When it comes to the English version of the text, questions were raised as to whether the rules were not 'too British' or, on the contrary, incompatible with English legal terminology. Although Latin is considered the lingua franca of European private law, the use of customary Latin phrases in the English version of the text was also criticised. It was also a challenge to find the appropriate English expressions for some standard distinctions in other languages e.g., the distinction between Lasten and Pflichten mentioned above. The Working Group also found that the use of certain phrases such as 'mediation' or 'conciliation' may need to be reconciled with the use of these terms in some Romance languages, for instance, Italian. ${ }^{33}$ Confronted with these challenges, the Working Group chose to avoid them by focusing on the essentials and using only generic inclusive expressions. It is expected, however, that these issues will reoccur when translating the rules into other European languages, which may be still another topic for discussion.

33 As argued by the Italian member of the Working Group (Prof. Silvestri), a number of legal systems derived from Roman law (and certainly Italy and France) distinguish between settlement (the contract by which the parties reach an agreement that ends their dispute thanks to the mutual acknowledgement of a few of the respective claims) and conciliation, which is the typical agreement reached by the parties while the proceeding is already pending. 


\section{CONCLUSIONS}

The work on the European Rules of Civil Procedure continues. In the next phases, the steering bodies of ELI and UNIDROIT will review the proposed rules and adopt their final form and content. ${ }^{34}$ The other working groups will finalise their proposals, which may take some time, as several of the groups in the last 'wave' have only recently been constituted. In the end, the proposals of all working groups will be discussed in the 'super-group' composed of reporters of all the groups. All rules will have to be streamlined and consolidated and therefore it is not likely that the final text of the completed rules will become public before the end of $2018 .{ }^{35}$

Nonetheless, even this incomplete work may be considered an important achievement. In the self-understanding of the Working Group, it has not introduced anything particularly new or revolutionary - just a detailed, concrete and systematic regulation and presentation of rules that are considered to be best practice in modern systems of civil procedure may highlight the desirable course of action for future procedural reforms. Elaborating the known principles, in the first place the principle of loyal cooperation of the parties and the court for the common goal of just, efficient and inexpensive adjudication, makes the proposed model text useful as a starting point for reformers of national rules. In addition, the systematic and coherent insistence on the shared responsibility of all the actors in the process for fair and effective civil proceedings could contribute to overcoming the doctrinal dichotomy between the adversarial and inquisitorial approaches to litigation, which marked the battlefield of procedural theory in the past. This is particularly valid for approaches to fact-finding and determination of applicable legal rules, where the proposed rules also avoid strict separation of duties and treat the determination of both facts and law as a joint and shared obligation of the court and the parties.

The proposed rules in their current form also clearly underline three of the most important reform trends in civil procedure in the last two decades. One highlights the importance of case management (and time management) in the proceedings. While in the past civil procedure was conceived as a journey into the unknown for many European jurisdictions (and also, seemingly, for some even today), the general trend of contemporary reforms is to put the emphasis on planning and preparation of the proceedings. Consequently, active participation in the early organisation of the proceedings is among the essential obligations of the judges, parties and lawyers in the draft Rules. This duty is also elaborated in further detail while at the same time attempting to find an appropriate balance between strict rules and general declarations of principle.

Another reform trend reflected in the draft Rules is the strengthening of the obligations of all actors - in particular of those who participate in the proceedings professionally, on a daily basis - to refrain from steps and actions that can be qualified as procedural abuse. The professional obligation to refrain from abusive procedural strategies, including vexatious behaviour and procedural steps aimed at delaying the procedure, is in particular highlighted as ethical and a legal duty of lawyers. By separating (procedural) obligations of the parties

34 On internal project workflow rules of ELI, <http://www.europeanlawinstitute.eu/projects/ project-workflow/> accessed 6 June 2017 .

${ }^{35}$ For the time being, the indicative schedule of the project foresees the presentation of five sets of rules (including the rules on obligations of parties, lawyers and judges) for Spring 2018 in Trier, Germany. This will also be the time when the remaining groups should present their first complete draft of rules. No indicative time limit for the adoption of the final set of rules has been set yet. 
and (ethical and procedural) obligations of lawyers, the draft Rules establish an (often absent) link between professional codes of conduct and civil procedural codes. The internalising of this link by professional associations such as bar associations (already present in some transnational rules for the European legal profession) should contribute to the formation and embrace of new ethics of the legal profession, an ethics in which both the adversaries and the court will be treated as partners, in spite of the divergence of their interests and procedural roles.

Finally, an important part of the obligations of the parties and their lawyers in the draft Rules transcends the boundaries of litigation and relates to their behaviour before initiating court proceedings. Encouraging parties' attempts to reach autonomous conflict settlement with a view to avoiding unnecessary involvement of public authorities describes an important trend in modern reforms in systems of civil justice in Europe and throughout the world. To that extent, the Working Group on obligations shared the opinion that resorting to litigation should only be the last route taken - ultimum remedium - when reasonable efforts by the parties in private disputes to resolve their differences have failed. ${ }^{36}$ Reasonable efforts in the draft Rules include all methods, from formal and informal direct communication and negotiations to a whole range of alternative dispute resolution mechanisms. The pre-procedural and procedural obligation of attempting autonomous dispute resolution (which stretches through the entire litigation process and continues in the post-action stages) is another shared obligation of all the actors in private civil disputes. As such, this obligation is another instance of the general obligation of loyal cooperation, this time in the attempt to deal jointly and autonomously with the different views regarding the substance of the dispute.

After their final adoption, it may be expected that the rules on obligations of parties, lawyers and judges, incorporated in the overall text of the European Rules of Civil Procedure, will be used as orientation and point of reference in future national reforms of civil procedural rules. Some inspiration hopefully will be drawn already from the incomplete and provisional results, in particular when they are presented to the public as a normative text with comments and explanations. Past experiences with the Transnational Rules of Civil Procedure show that, with time, their prominence and influence increased. Due to a broader circle of involved experts, many interested observers, stronger institutional support and a higher level of elaboration with a particular regional (European) flavour, the European Rules of Civil Procedure may begin to be adopted even faster. Naturally, due to the structural differences between European civil justice systems ${ }^{37}$ it is hard to believe that many countries will adopt the text of the rules word for word. ${ }^{38}$ But the adoption of the spirit and philosophy of the ELI/UNIDROIT Rules may play an even greater role than a mechanical copying of 'harmonised' European phrases. This is why one can reasonably hope that even this sketchy presentation of the unfinished work of the ELI Working Group on Obligations of Parties, Lawyers and Judges may be useful in future discussions of procedural reformists.

36 Indeed, the members of the Working Group do not dispute the public purpose of litigation and the need for court involvement in disputes with prevailing public interest. On the various goals of civil litigation, see more in Uzelac (2014).

37 On these structural differences and their impact on the possibility of harmonisation, see Uzelac (2012).

${ }^{38}$ For this statement - not only in respect of civil procedure - the best proof may be the experiences with the adoption of model legislation of UN bodies, such as UNCITRAL. 


\section{LITERATURE}

Código Iberoamericano De Ética Judicial, (2006) <http://www.poderjudicial.gob.hn/CUMBREJUDI CIALIBEROAMERICANA/Documents/CodigoEtico.pdf $>$.

Council of Europe, Committee of Ministers, Recommendation No. $R$ (84) 5 of the Committee of Ministers to Member States 'On the Principles of Civil Procedure Designed to Improve the Functioning of Justice'.

Ervo L., Gräns M., and Jokela, A. (eds), Europeanization of Procedural Law and the New Challenges to Fair Trial (Europa Law Pub. 2009).

Ervo, L., and Nylund, A. (eds), Current trends in Preparatory Proceedings. A Comparative Study of Nordic and Former Communist Countries (Springer 2016).

European Parliament, Council of the European Union, Directive 2008/52/EC of the European Parliament and of the Council of 21 May 2008 on Certain Aspects of Mediation in Civil and Commercial Matters (2008).

Joint American Law Institute / UNIDROIT Working Group on Principles and Rules of Transnational Civil Procedure, ALI/UNIDROIT Principles of Transnational Civil Procedure. Appendix: rules of transnational civil procedure (A Reporter's Study), (2005).

Klein, F., Pro Futuro. Betrachtungen über Probleme der Civilprozeßreform in Oesterreich (Deuticke 1891).

Manko, R., Europeanization of civil procedure. Towards common minimum standards? (European Parliament EPRS PE 559.499, 2015).

Storme, M. (ed), Approximation of Judiciary Law in the European Union (Kluwer 1994).

The Council of Bars and Law Societies of Europe (CCBE), The Charter of Core Principles of the European Legal Profession and Code of Conduct for European Lawyers (Brussels 2013).

Tulibacka, M., Blomeyer, R., and Sanz, M., Common minimum standards of civil procedure (European Parliament EPRS PE 581.385, 2016).

Uzelac, A., 'Harmonised Civil Procedure in a World of Structural Divergences? Lessons Learned from the CEPEJ Evaluations' in Kramer, X.E. and van Rhee, C.H. (eds), Civil Litigation in a Globalising World (T.M.C. Asser Press and Springer 2012) 175-205.

Uzelac, A., 'Croatia: Omnipotent judges as the Cause of Procedural Inefficiency and Impotence' in van Rhee and Fu (eds), Civil Litigation in China and Europe (Springer 2014) 197-221

Uzelac, A. (ed), Goals of Civil Justice and Civil Procedure in Contemporary Judicial Systems (Springer 2014). [Uzelac (2014b)].

Van Rhee, C.H., 'Obligations of the Parties and their Lawyers in Civil Litigation: The ALI/UNIDROIT Principles of Transnational Civil Procedure' in J., Adolphsen et al., Festschrift für Peter Gottwald zum 70. Geburtstag (Beck 2014) 689-99.

Van Rhee, C.H. and Fu, Y. (eds), Civil Litigation in China and Europe. Essays on the Role of the Judge and the Parties (Springer 2014).

Woolf, H.K., Access to Justice, Interim Report (Lord Chancellor's Department June 1995).

Woolf, H.K., Access to Justice, Final Report (H.M. Stationery Office 1996).

Zuckerman, A.A.S. (ed), Civil Justice in Crisis. Comparative Perspectives of Civil Procedure (Oxford UP 2000). 